\title{
STUDY AND ANALYSIS ON TECHNOLOGY AND DEVELOPMENT OF INFORMATION NETWORK OF RURAL POWER GRID
}

\author{
Weiying $\mathrm{Li}^{*}$ \\ College of Information Science and Technology,Agriculture University of HeBeii \\ HeBei,Baoding 071001, China \\ * Corresponding author, Address: College of Information Science and Technology, \\ Agriculture University of HeBei HeBei,Baoding 071001, China, Tel: +86-312-7526424, \\ Email:leeweiying@163.com
}

\begin{abstract}
This paper describes the technology and transferring mode of rural power grid's information network, analyses technology of communication system of electric power grid in rural area, chooses a new develop direction of technique based on the business needs and trend of rural power grids, and gives a route for development.
\end{abstract}

Keywords: rural power grids, Information network, SDH, MSTP

\section{INTRODUCTION}

During recent years, the advanced technology and systems are used in electric communication network, the construction of communication and information network for rural power grid is developing at top speed. The electric power enterprises are beginning to construct the information network for rural area to meet the needs of information and communication during the rural power grid's development when compared with the rural power grid upgrade. The information and communication systems of rural power grid are diversified in technical structures and operation patterns based on their own practices and levels of economic development. This paper analyzes and inquiries the mode of planning and developing a network in rural area.

Please use the following format when citing this chapter:

Li, W., 2009, in IFIP International Federation for Information Processing, Volume 295, Computer and Computing Technologies in Agriculture II, Volume 3, eds. D. Li, Z. Chunjiang, (Boston: Springer), pp. 1855-1862. 


\section{SERVICE ANALYSIS FOR RURAL POWER INFORMATION NETWORK}

The rural power information network is the platform to provide information and communication service for electric power supply company in the executive grade which is at county level or below.

It serves the domain of production, administration and capital construction for the company. It supports the services of dispatching telephone, administration telephone, and automation of electric network management, relay protection, safety automation, computer linkups and image transmission and so on. If classified by service, they can be labeled to voice traffic service, low speed data service, high speed data service and video service. If classified by specialized field, they can be labeled to dispatching and administration voice information, rural power supply running supervision information, videoconference information, real time video surveillance information and administrative management information.

The description of access and transmission pattern of the services mentioned is listed below:

(1) Dispatching and administration telephone

It is a part of traditional services for voice. As the important platform for dispatching and administration, it must have high reliability and fast connection speed. It is mainly made of PBX or the extend of dispatching exchange and interfaces between exchanges such as FXS、FXO、4W+ E/M、E1 and so on. The proportion of voice traffic service continues to drop because of the transform of rural power's communication pattern.

(2) Video surveillance information of substation

Video surveillance is the supplement to the remote control after carrying out the mode of unattended operation in rural substation. It provides the more precise circumstances to operators. And it can help the person in command or on duty quickly determine and make a strategic decision remotely in case of emergency. It adopts the network interface of TCP/IP and 10/100Base-T. (3) Management information system (MIS)

MIS in rural power Supply Company supplies the inquiry function of business enlargement and daily operation, electricity meters, electric power changes, electro-inspections by using control technique, graphics technique, database technology, network technology and multimedia. The computer linkups between various departments and subsidiaries of the company are based on the rural information and communication network of power Supply Company.

(4) The real time data of Automation of Electric Network Management

It is used to remotely monitor and control the equipments and collect realtime data for Control Center. This type of data has high requirement for high reliability and less time delay. It has the forms of voice data, serial data and 
TCP/IP data. The TCP/IP data can access the SDH by Network Bridge or direct access the IP port. The RS-232/485 data can access the IP port through the RS-232/485 port of PCM equipment or access the IP port after being converted by terminal server.

(5) Relay protection signal

The relay protection signal has high requirement for high reliability. It can access the SDH through G.703/64kbps port of PCM equipment. The administration information of protective relay unit can be switched in through RS-232/485 port of VPN or PCM equipment.

(6)Video conference service

It is one of the principal services transported by electric communication network. The video conference network system that is based on IP and runs on packet switching network and adopts the H.323 protocol is progressively approved by electric power enterprises along with the perfection of H.323 protocol. The access method of TCP/IP will be adopted more and more hereafter.

(7) others

The subsidiary business of communication supporting networks and monitor message can be carried by the manners of TDM or IP.

In addition, there are services of lightning monitor system, network application, E-mail and document transmission.

The characteristic of the services mentioned above can be concluded in the figure below:

Table1. Traffic analysis of the Power Private Communication Network in rural area

\begin{tabular}{|c|c|c|c|c|c|c|c|}
\hline & $\begin{array}{c}\text { Transmission } \\
\text { rate } \\
\end{array}$ & $\begin{array}{c}\text { Transmission } \\
\text { delay }\end{array}$ & $\begin{array}{c}\text { Error } \\
\text { rate }\end{array}$ & Usability & Integrity & Configuration & Protocol \\
\hline \multicolumn{2}{|l|}{ Data traffic } & \multirow{3}{*}{ classification } & \multirow{7}{*}{$\leq 10^{-5}$} & & \multirow[b]{2}{*}{ high degree } & \multirow[b]{2}{*}{$\begin{array}{c}\text { Broadcast/ } \\
\text { double action }\end{array}$} & \multirow[b]{2}{*}{ IP } \\
\hline MIS & $4 \mathrm{Mbps}$ & & & & & & \\
\hline \multicolumn{2}{|c|}{ Multi-media service } & & & & & & \\
\hline $\begin{array}{l}\text { Video } \\
\text { conference }\end{array}$ & 2Mbps & $\leq 400 \mathrm{~ms}$ & & higher & moderate & $\begin{array}{c}\text { Broadcast/ } \\
\text { double action }\end{array}$ & TDM/IP \\
\hline E-mail & $256 \mathrm{Kbps}$ & classification & & moderate & moderate & & IP \\
\hline $\begin{array}{l}\text { Network } \\
\text { application }\end{array}$ & $2 \mathrm{Mbps}$ & second & & moderate & moderate & & IP \\
\hline $\begin{array}{l}\text { Document } \\
\text { transmission }\end{array}$ & $2 \mathrm{Mbps}$ & minute & & moderate & moderate & & IP \\
\hline Gis & $512 \mathrm{Kbps}$ & second & & higher & higher & & IP \\
\hline $\begin{array}{l}\text { Video } \\
\text { surveillance }\end{array}$ & $2 \mathrm{Mbps}$ & $\leq 400 \mathrm{~ms}$ & $\leq 10^{-5}$ & higher & moderate & $\begin{array}{c}\text { Broadcast/ } \\
\text { double action }\end{array}$ & TDM/IP \\
\hline \multicolumn{2}{|c|}{ Telephone service } & & & & & & \\
\hline $\begin{array}{l}\text { Dispatching } \\
\text { telephone }\end{array}$ & $64 \mathrm{Kbps}$ & $\leq 250 \mathrm{~ms}$ & $\leq 10^{-5}$ & high degree & high degree & double action & TDM/AAL 1 \\
\hline Office phone & $64 \mathrm{Kbps}$ & $\leq 250 \mathrm{~ms}$ & $\leq 10^{-5}$ & high degree & common & double action & TDM/AAL 1 \\
\hline IP telephone & $16-64 \mathrm{Kbps}$ & $\leq 250 \mathrm{~ms}$ & $\leq 10^{-5}$ & high degree & common & double action & IP \\
\hline
\end{tabular}


Several conclusions flow from this figure: the data communication is replacing speech communication based on TDM by degrees in the information network along with the development of rural power grid; The increasing data traffic based on IP is carried and the various kinds of services have different request of transmission quality; At the same time, the traditional services based on TDM will exist for a long time.

\section{TECHNIQUE ANALYSES FOR RURAL POWER INFORMATION NETWORK}

With the rural power grid upgrade, a fairly large electric private networks based on SDH are established in many rural areas which support the informationization of the rural power supply. However, restricted by the investor and the works scope, the structure of communication network has weak links because the communication facilities are constructed in the wake of the rural power grid upgrade. The SDH technology that mainly carries the single TDM service can not support the IP data and the view data service efficiently which have increasing proportion, so the bandwidth is wasted. The characteristic that need to be regulated is list below:

(1)The network of chain structure has low reliability.

The topological structure of information network for rural power grid at present depends on the trend of power line which has the star configuration or chain structure. The existent rural power grid has an irregular structure, which causes the low reliability of communication network.

The optical network protection can be classified according to its physical topology as line protection and self-healing ring configuration, the ring pattern can self recovery the network from failure within less than $50 \mathrm{~ms}$. But the present situation of rural network only permits line protection and the self-healing ring configuration is unattainable. In some area there is only chain structure and there are even not ADM facilities but only TM facilities, the security of SDH is not fulfilled.

(2) IP service is not supported

The traditional SDH system in rural network mainly transports TDM service such as voice. It holds an advantage on performance monitoring of network, failure recovery and reliability. It is adequate for the time sensitive service. However, SDH is an architecture that has the characteristic of complicated and centralized supply and limited expansibility. It can't handle the IP service which has the characteristics of burst ness and unbalanced ness. It hasn't got the expansibility and flexibility which is needed in the network that mainly transports the IP service. The Virtual Container can't match the bandwidth of IP packet. It causes the low utilization rate of bandwidth. The SOH of SDH can't fit the IP environment. Along with the 
increasing of data service, SDH can't directly support the $10 \mathrm{Mbps}, 100 \mathrm{Mbps}$ and $1000 \mathrm{Mbps}$ ports of IP network.

The SDH system has a large proportion in rural network. At the same time, the solution based on SDH will play an important role in the future because of its maturity, reliability and full cost. So the construction of rural electric communication network should build the architecture that has the characteristics which both faces the IP service in the future and supports the TDM system at present.

\section{THE CHOICE OF TECHNICAL STRUCTURES}

The demand to rural electric communication network according to the current business is:

(1) Switch in the broadband service efficiently through layers as few as possible.

(2) The proportion of TDM service is brought down but remains high reliability.

(3) Support the video service efficiently.

(4) The dynamic data traffic is carried by dynamic linked network.

(5) Unify the network to build and maintain expediently.

Based on the request for technology mentioned above and to support the increasing IP service preferably, the network operator of rural electric power system are focusing the technology system such as DWDM, RPR and MSTP when building the private network or upgrading the existing SDH network. Furthermore, the pure IP network and the NGN, Soft Switch are receiving more attention. The data traffic is developing rapidly these years, but the TDM service such as dispatching telephone needs being first and foremost considered because of the particularity of electric power system. The pure IP network is not adequate for power grid because it can't meet the need of the reliability of QOS for TDM service.

For the areas where the SDH network already has been established, to protect the investment, it should be upgraded to the communications network that is suitable for IP service from existing equipments and technology system. It means that a plan is needed to transit the static multiplexed mode to dynamic IP network mode.

For the areas that the local rural electric communication network has not been established, a conformable technique structure should be chose to meet the need of specific service. Table2 is the analysis of technical in the power private communication network in rural area. 
Table2. Technical analysis of the Power Private Communication Network in rural area

\begin{tabular}{|c|c|c|c|c|}
\hline $\begin{array}{c}\text { Technology } \\
\text { Characteristic }\end{array}$ & Traditional SDH & MSTP & WDM & RPR \\
\hline Summarize & $\begin{array}{l}\text { Chief component of } \\
\text { existing power private } \\
\text { communication } \\
\text { network }\end{array}$ & $\begin{array}{l}\text { Optimize the data } \\
\text { service retaining the } \\
\text { advantage of sdh }\end{array}$ & Transport mass of data & $\begin{array}{l}\text { Optimize the sdh } \\
\text { network aiming at } \\
\text { data service }\end{array}$ \\
\hline Emphasis & $\begin{array}{l}\text { It is adequate for time } \\
\text { sensitive service such } \\
\text { as voice }\end{array}$ & $\begin{array}{l}\text { Bring together services } \\
\text { on the VC1 level and } \\
\text { support varies service } \\
\text { interfaces }\end{array}$ & $\begin{array}{l}\text { Transport multi } \\
\text { wavelength at high } \\
\text { speed }\end{array}$ & $\begin{array}{l}\text { Bring together and } \\
\text { transport data service, } \\
\text { especially the } \\
\text { Ethernet }\end{array}$ \\
\hline $\begin{array}{l}\text { Technical } \\
\text { Description }\end{array}$ & $\begin{array}{l}\text { Fit the mixed service } \\
\text { based on the principle } \\
\text { of TDM }\end{array}$ & $\begin{array}{l}\text { The integrated function } \\
\text { for transmission and } \\
\text { traffic grooming; the } \\
\text { optional function for } \\
\text { data layer gathering }\end{array}$ & $\begin{array}{l}\text { OADM、DWDM、 } \\
\text { CWDM based on ring } \\
\text { network or DWDM、 } \\
\text { CWDM point-to-point }\end{array}$ & $\begin{array}{l}\text { Data gathering and } \\
\text { exchange } \\
\text { equipment, the } \\
\text { limited ability for } \\
\text { voice processing }\end{array}$ \\
\hline Advantage & $\begin{array}{l}\text { The equipments have } \\
\text { been set up in } \\
\text { abundance, which have } \\
\text { proven technique and } \\
\text { high reliability }\end{array}$ & $\begin{array}{l}\text { The existing SDH } \\
\text { equipment are } \\
\text { compatible, it is rapidly } \\
\text { to open any new } \\
\text { business and the } \\
\text { network equipment is } \\
\text { decreased }\end{array}$ & $\begin{array}{l}\text { The capacity is largely } \\
\text { increasing. The } \\
\text { transparent service } \\
\text { based on wavelength } \\
\text { can be supported. Any } \\
\text { protocol can be } \\
\text { transported neatly }\end{array}$ & $\begin{array}{l}\text { Effective data } \\
\text { gathering function }\end{array}$ \\
\hline Shortcoming & $\begin{array}{l}\text { Lower efficiency after } \\
\text { the data service } \\
\text { becomes the dominant }\end{array}$ & $\begin{array}{l}\text { Packing too more } \\
\text { features lead to the } \\
\text { difficulty for } \\
\text { deployment }\end{array}$ & $\begin{array}{l}\text { Can't gathering the low } \\
\text { speed signal to } \\
\text { wavelength channel, } \\
\text { can't deploy the } \\
\text { wavelength } \\
\text { dynamically, high cost }\end{array}$ & $\begin{array}{l}\text { Lack of ability for } \\
\text { voice processing }\end{array}$ \\
\hline
\end{tabular}

A conclusion can be drawn from the table that MSTP has resolved the conflict of transporting TDM service and data service at same time. It is a good option to optimize the network on condition that plenty of SDH systems have been constructed by the rural power supply companies and the voice service is holding important positions.

To better suit the dynamic variation characteristic of data service, MSTP (Multi Service Transport Platform) appends the data processing function to SDH equipment. It integrates the SDH multiplexer, DXC, network switch and PE pouter into one network equipment named MSTP to be jointly controlled. So the MSTP can support both the existent TDM service and the ever-growing IP data service, its technology for building up and protection follows SDH.

MSTP is now in the third generation, its key technology includes 1. Virtual Concatenation: it avoids the bandwidth wasting through providing the more flexible organization of channel capacity to do well meeting the increasing needs of data service.2. Generic Framing Procedure: it is a simple and effective encapsulation method that organizes the data service in denomination of frame. It can transport both fixed-length block data and variable-length data packet in synchronous link.3. Link Capacity Adjustment Scheme: it is control mechanisms to increase and reduce the circuit capacity between the source/sink adapt ion function of virtual concatenation. It can clearly develop the network utilization starting from the premise of 
guaranteed service quality and in the environment of the burst data service.4. Intelligent Adapter Layer: it is lead in between Ethernet and SDH/SONET. It adapts SDH and Ethernet through adopting LAPS protocol and satisfies the QOS of Ethernet service. So we can say that the MSTP system provides a suitable solution to the construction of rural electric communication network.

\section{CONCLUSIONS}

The focal point to be considered by the rural electric department is to plan and construct the network with a technical structure that fits the current services.

The current developing trend of the rural electric communication network is to support the IP and Ethernet starting from the premise that the TDM service is transported reliably.

For the rural power supply company who has a mass of SDH network, MSTP can support the data traffic effectively, so it protects the huge investment of intrinsic SDH equipments and guarantees the sustainable development of the rural power grids information network. The MSTP of third generation has lead in many access functions in connection with the different applications. It can optimize the network at low cost through the comprehensive application of multiple functions. The high reliability is preserved at the same time.

In addition, the design practice of ring network should be preferred to give full play to the reliability of it. As much substation as possible should be switched in the ring through breaking the administrative division limit.

The OPGW and ADSS patterns of optical-fiber cable lying should be given priority to because there are the ready resources of electric tower. The communication and information network for rural power grid should form a backbone network for electric information business expansion that adapts the organizational structure and managing mode of electrical grid to provide high-speed and reliable platform for the transmission and switching system in rural electric information network.

\section{REFERENCES}

GAO Xin-zhong, The Evolution of Shanxi Electric Power Optical Fiber Communication Network, Shanxi Electric Power 2007.1

Greenville Armitage,MPLS:The Magic Behind the Myths, IEEE Communications Magazine 2000,P 124-131

Harry L Bosco ,Evolution of the Wide Area Network, Bell Laboratories Technical Journal 2000 , P 46-72 
Huston G, Next Steps for the IP QoS Architecture http://draft-iab-qos- 00. Txt 2000 Morgan Stanley Research ,The Metro Optical Report: The Return of the RBOCs.

Richard Comerford,Technology 2000 Analysis and Forecast Computing IEEE Spectrum 2000 P 4S-49 